\title{
FRIEDRICH RATZEL
}

\author{
LUCIANA DE LIMA MARTINS ${ }^{1}$
}

Friedrich Ratzel (1844-1904) é considerado por muitos o fundador da moderna geografia humana, sendo responsável também pelo estabelecimento da geografia política como disciplina. A abrangente produção ratzeliana deixa transparecer a integração de fatos da modernidade e do rápido desenvolvimento da sociedade no contexto da Alemanha que se unificava. Reflexões sobre o Estado, a história, as raças humanas, o ensino da geografia e a descrição de paisagens perpassam a obra do geógrafo, que se preocupava em auferir uma identidade comum à nação em formação. No Brasil, é o Ratzel determinista que se destaca na produção historiográfica da geografia, resultado da leitura da obra ratzeliana através da literatura francesa, sobretudo da obra de Lucien Febvre - La Terre et L'Évolution Humaine (1922) - que estigmatizou a pecha de determinista para Ratzel em contraposição ao possibilismo de Vidal de la Blache, termo cunhado pelo próprio Febvre (cf. Moreira, 1989:32 e Moraes, 1990:13).

Ratzel inicia sua carreira acadêmica em 1866 como zoólogo, interesse despertado pelo considerável impacto da obra de Charles Darwin na Europa, e de seu discípulo alemão Ernst Haeckel. Correspondente do jornal Kölnische Zeitung desde 1868, Ratzel teve a oportunidade de viajar pelo sul da França, pela Itália e pelo leste Europeu. Em suas impressões sobre natureza e paisagem, ocupação humana e nacionalidade, pode-se perceber a mudança do cientista natural para o geógrafo. De 1873 a 1875, Ratzel trabalha como correspondente na América do Norte, percebendo o surgimento de uma nova sociedade através do ambiente antrópico e de seu uso, e prevê um futuro essencialmente urbano para a sociedade moderna, no bem e no mal.

O interesse pelo estudo da migração chinesa (Die chinesische Auswanderung, 1876), com o qual completa sua qualificação acadêmica, foi também suscitado na sua viagem à América.

De 1875 a 1886, Ratzel leciona geografia na Politécnica de Munique, combinando seu vasto conhecimento da literatura da disciplina com a riqueza, de dados e informações obtidos em suas viagens e pesquisas de campo. Geografia física, geografia regional dos continentes, geografia humana e política foram todos temas dos cursos mais substanciais. Em 1886, Ratzel transfere-se para a Universidade de Leipzig, onde permanecerá até sua morte, em 1904. Jean Brunhes, Ellen Semple, Hans Helmolt e Alfred Hettner foram alguns dos mais ilustres estudantes e orientandos de Ratzel nesse período. O geógrafo divide seu tempo trabalhando na formação de professores para as escolas públicas e no fomento de aulas de geografia nessas escolas, publicando o livro didático Deutschland (1898) para combater a aspereza das aulas de geografia e "despertar a vontade de obtenção de um conhecimento e de uma concepção da terra natal (Heimat) não envolvidos apenas com o intelecto" (citado por Buttman, 1977: p. 83). Em Leipzig, Ratzel vai também aprofundar seu conhecimento filosófico através dos encontros com o chamado "Círculo de Leipzig", um grupo de intelectuais interessados sobretudo na obra de Leibniz, que terá

1 Mestre (1993) e doutora (1998) em Geografia pela UFRJ, desde 1999 trabalha como pesquisadora do Grupo de Geografia Social e Cultural de Royal Holloway, Universidade de Londres. A Introdução baseia-se principalmente em Martins (1993). A autora agradece a inestimável ajuda do prof. Ferdinand Reis, sem a qual a tradução do artigo de Ratzel não se viabilizaria 
influência marcante na produção ratzeliana dos últimos anos de sua vida.

Em linhas gerais, a obra de Ratzel é uma tentativa de superar uma geografia puramente descritiva e de avançar na formulação de grandes construções explicativas, onde o "sentido de espaço" (Raumsinn) ocupa lugar primordial. Das fecundas idéias ratzelianas, destacam-se principalmente:

1) O estudo dos efeitos recíprocos entre o homem e seu ambiente, onde o homem teria um duplo posicionamento: ativo, na medida que transforma, através de seu trabalho, a superfície terrestre, e passivo, na sua dependência das condições naturais, que seu espaço vital (Lebensraum) lhe impõe (Anthropogeographie, vol. 1, 1882);

2) O papel importante desempenhado pela cultura e pela difusão cultural (Völkerkunde, 1885-8);

3) As relações entre o homem e a natureza devem ser compreendidas não somente sob o ângulo da mediação técnica ou econômica (trabalho, progresso), mas também, e sobretudo, levando se em consideração a mediação política: Ratzel compara o Estado a um organismo (Politische Geographie, 1897). No entanto, o "organismo" político a que Ratzel se refere difere da estrutura rudimentar do organismo biológico, na medida em que expressa a unidade orgânica do homem e da Terra, incluindo todos os objetos perceptíveis, materiais e imateriais, vinculando-se ao conceito da unidade (Ganzheit) de matriz romântica;

4) A importância básica da geografia física para toda a pesquisa geográfica (Die Erde und das Leben, 1901-2);

5) A descrição artística da natureza e da paisagem deve preencher tanto as necessidades científicas como as estéticas (Über Naturschilderung, 1904).

O texto de Ratzel aqui traduzido - "Freunde, im Raum wohnt das erhabene nicht!" (Amigos, o sublime não mora no espaço!) - foi publicado em 1903 no periódico Glauben und Wissen (Fé e Saber) e insere-se no primeiro volume da obra póstuma Kleine Schriften von Friedrich Ratzel (Pequenos escritos de Friedrich Ratzel), organizada por Hans Helmolt, em 1906. Trata-se de uma coletânea de cerca de 86 artigos publicados em diversos periódicos de 1867 a 1904, que conta ainda com uma biografia escrita pelo organizador e de uma bibliografia levantada por Viktor Hantzsch. Nesses artigos, encontra-se ora um Ratzel reflexivo, ora inflamado, ora crítico. Despojado da rigidez acadêmica, da preocupação da sistematização do pensamento geográfico enquanto disciplina, como em suas principais obras - Anthropogeographie e Politische Geographie -, aflora, nos Kleine Schriften, um Ratzel multifacetado, engajado politicamente, envolvido com questões filosóficas, artísticas e religiosas. Os artigos tratam desde a anatomia do Enchytraeus vermiculares a considerações sobre a fisionomia da Lua, glaciologia, etnografia, história, colonialismo na África, paisagens, panoramas, fotografia, escritos biográficos, geografia política, cidades, nacionalidades e raças.

A seleção deste texto em particular para ser traduzido, dentre tantos, deve-se à curiosidade suscitada pelo momento em que foi produzido, a chamada fase "madura" da obra ratzeliana. A humildade intelectual subjacente ao questionamento que Ratzel se permite fazer, em que busca explorar "as contradições da visão do mundo entre conhecimento das ciências naturais e fé cristã" (Buttmann, 1977:102), propiciou a sintonia com seu pensamento, o encontro, a mediação entre seu mundo e o atual. Nesse texto, o geógrafo faz uma profissão de fé, reconhece o intransponível, o insondável, mas não toma, perante este fato, uma atitude niilista. Apenas está consciente da existência de limites que, longe de provocarem-lhe desânimo, incitam-no a prosseguir seu caminho. No momento atual, em que se repensam os caminhos e descaminhos da atividade científica e do projeto da modernidade, e o lugar da geografia nesse contexto, a reflexão ratzeliana é digna de atenção. 


\section{Referências bibliográficas:}

BUTTMANN, G. 1977. Friedrich Ratzel; Leben und Werken eines deutschen geographen. Stuttgart, Wissenschaftliche Verlagsgesselschaft.

MARTINS, L. 1993. Friedrich Ratzel através de um prisma. Rio de Janeiro, UFRJ (dissertação de mestrado).

MORAES, A. C. R. (org.). 1990. Ratzel. São Paulo, Atica.

MOREIRA, R. 1989. O que é Geografia. São Paulo, Brasiliense. 